\title{
Physicochemical and biochemical properties of an acid soil under potato culture amended with municipal solid waste compost
}

\author{
Marta Domínguez ${ }^{1,2} \cdot$ Remigio Paradelo Núñez $^{1} \cdot$ Juan Piñeiro $^{3} \cdot$ María Teresa Barral $^{1}$
}

Received: 24 October 2018 / Accepted: 5 February 2019 / Published online: 12 February 2019

(c) The Author(s) 2019

\begin{abstract}
Purpose A field trial was conducted on a silty-loam soil under potato culture in NW Spain, to assess the effect of municipal solid waste (MSW) compost in a heavily fertilized acid soil.

Methods Three doses of compost $\left(0,30\right.$ and $60 \mathrm{Mg}$ compost ha $^{-1}$ soil) or inorganic fertilization ( 140 N: $120 \mathrm{P}_{2} \mathrm{O}_{5}$ : $240 \mathrm{~K}_{2} \mathrm{O} \mathrm{kg} \mathrm{ha}{ }^{-1}$ soil) were assayed. The effects of compost on soil physical, chemical (nutrient status and potentially toxic trace elements) and biochemical properties were evaluated after 1 and 5 months.

Results Compost addition at the highest dose decreased bulk density and increased soil porosity and soil stability against water erosion. Soil $\mathrm{pH}$, total organic $\mathrm{C}$ and $\mathrm{N}$, cation exchange capacity and available $\mathrm{P}, \mathrm{Ca}, \mathrm{Mg}$ and $\mathrm{K}$ were also higher in compost-amended soils, whereas no effect on $\mathrm{NH}_{4}{ }^{+}-\mathrm{N}_{\text {and }} \mathrm{NO}_{3}{ }^{-}-\mathrm{N}$ was observed. Compost significantly increased soil microbial biomass and dehydrogenase activity. Due to the high nutrient status in the control soil, potato yield was not increased by compost or inorganic fertilization. A negative consequence of compost addition was the increased extractability of trace metals such as $\mathrm{Zn}, \mathrm{Cu}, \mathrm{Pb}$ and $\mathrm{Ni}$, although their total concentrations in soil or in potato tubers did not increase with respect to the control.

Conclusions Overall, results show that positive effects of MSW compost can be expected even in rich soils that do not need fertilization for maintaining their productive function in the short-term. These positive effects prove the benefits of recycling urban wastes in agricultural soils as a sustainable way of waste management.
\end{abstract}

Keywords Organic amendments $\cdot$ Soil quality $\cdot$ Microbial biomass $\cdot$ Heavy metals

\section{Introduction}

Agricultural activities may result in a decrease in soil organic carbon (SOC) in cultivated soils in comparison with their non-cultivated counterparts when losses are not sufficiently compensated by inputs. Tillage and the progressive replacement of organic amendments by inorganic fertilizers

Remigio Paradelo Núñez

remigio.paradelo.nunez@usc.es

1 Departamento de Edafoloxía e Química Agrícola, Facultade de Farmacia, Universidade de Santiago de Compostela, Praza Seminario de Estudos Galegos S/N, Campus Sur, 15782 Santiago de Compostela, Spain

2 Fomento de Construcciones Y Contratas, Planta de Tratamiento de Residuos de Lousame, Servia (Lousame), A Coruña, Spain

3 Centro de Investigaciones Agrarias de Mabegondo (CIAM), Apdo. 10, A Coruña, Spain are among the processes that have contributed to the loss of soil organic matter (SOM) in cropped soils. Given the key role of organic matter in soil functions and agricultural sustainability, the maintenance of appropriate soil organic matter levels is essential to ensure soil quality and sustainability of soil use (Barral et al. 2009). Urban wastes and in particular municipal solid waste (MSW) are interesting sources of organic matter for agricultural soils now that urban areas are increasing at expenses of rural areas. Through composting, urban wastes can be transformed in safe soil amendments (Farrell and Jones 2009) that have been demonstrated to be of use in low-fertility, degraded or low-quality soils, where nutrient and organic matter inputs are necessary to restore productivity (Hargreaves et al. 2008; Park et al. 2011; Paradelo 2013; Rady et al. 2016). Notwithstanding, the problem with urban wastes is growing and compost use should be envisaged also for agricultural soils that do not necessarily need an increasing of fertility or organic matter content. In this case, potential negative effects of urban wastes, such as 
excess nutrient leaching or accumulation of potentially toxic elements, must be taken into account.

This is the case of composts produced from urban wastes such as MSW that may be the cause of negative effects when added to soil due to the presence of high concentrations of potentially toxic trace elements (Smith 2009; Lopes et al. 2011; Paradelo et al. 2011). Among these, $\mathrm{Pb}, \mathrm{Cu}$, and $\mathrm{Zn}$ often reach high concentrations in composts due to the inadequate separation of MSW biodegradable fractions from non-degradable or inert materials rich in metals, as well as to their presence in vegetables and other human food materials (Chaney et al. 2001), and they could be accumulated in soils up to excessive levels after repeated compost applications. Consequently, concern about the risk of soil pollution by contaminants has led to the development of European and national guidelines controlling the use of these materials (Barral and Paradelo 2011).

When working with degraded systems, where soil fertility must be restored before any other consideration, these potential drawbacks can be considered a minor concern. In turn, if MSW composts are to be used in fertile soils with soil functions other than plant production in mind, environmental issues gain relevance. In this sense, the general objective of this work was to know what happens in very fertile and organic matter-rich soils: whether, in this case, the potential advantages of composts beyond plant yield have more weight than the associated risks. Thus, we have evaluated the effects of the application of municipal solid waste compost on the properties of an agricultural soil under an Oceanic climate throughout the cycle (5 months) of a potato (Solanum tuberosum L.) culture, in comparison with soil receiving inorganic fertilization. Physical, chemical and biochemical properties have been assessed, as well as crop yield and potential transfer of heavy metals to the edible parts of potatoes.

\section{Materials and methods}

\section{Site description and treatments}

The field trial site was located in the CIAM Agricultural Research Station in Mabegondo (A Coruña, Spain), at $43^{\circ}$ $15^{\prime} \mathrm{N}$ and $8^{\circ} 16^{\prime} \mathrm{W}$. The site $(120 \mathrm{~m}$ above the sea level) is a nearly flat area of c.a. $540 \mathrm{~m}^{2}$ on weathered biotite schist. Climate is Oceanic, with a mean annual temperature of 12.3 ${ }^{\circ} \mathrm{C}$, mean annual rainfall of $1169 \mathrm{~mm}$ and annual evapotranspiration of $766 \mathrm{~mm}$. The soil was a silty-loam Eutric Cambisol (IUSS Working Group WRB 2014), with 25\% sand and $19 \%$ clay, acid ( $\mathrm{pH}$ in water 5.6 and 5.0 in $0.1 \mathrm{~N} \mathrm{KCl}$ ), rich in organic matter $(3.4 \% \mathrm{OM}, 0.19 \%$ total $\mathrm{N})$ and nutrients (443 mg kg${ }^{-1}$ and $293 \mathrm{mg} \mathrm{kg}^{-1}$ for available $\mathrm{K}_{2} \mathrm{O}$ and $\mathrm{P}_{2} \mathrm{O}_{5}$ respectively, and 1865 and $76 \mathrm{mg} \mathrm{kg}^{-1}$ for available $\mathrm{CaO}$ and $\mathrm{MgO}$, respectively). The 10 months previous to the beginning of the experiment the plot remained uncultivated and was disk-harrowed twice, in autumn and spring.

The field trial comprised four replicates of four treatments (two doses of compost, one dose of inorganic fertilizer and a control), applied to subplots of $8 \times 4.2 \mathrm{~m}$, set out in a Latin square design. The application of 30 and $60 \mathrm{Mg}$ compost $\mathrm{ha}^{-1}$ (fresh weight) will be referred to as SC1 and SC2, respectively. The application of inorganic fertilizer N:P:K (12:12:24) at a dose $1000 \mathrm{~kg} \mathrm{ha}^{-1}$, commonly used for potato culture in the region, plus $\mathrm{NH}_{4} \mathrm{NO}_{3}$ at a dose of $100 \mathrm{~kg} \mathrm{ha}^{-1}$ soil will be referred to as SIF. Control plots without compost or inorganic fertilizer will be referred to as $\mathrm{S}$. The treatments assayed in the experience are summarized in Table 1.

The compost employed in the trial was produced by an industrial composting plant, through aerobic transformation of separately collected organic fraction of municipal solid waste (MSW), and its characteristics are indicated in Table 2. The $\mathrm{pH}$ was near neutrality, the $\mathrm{C} / \mathrm{N}$ ratio 13 is indicative of maturity, available $\mathrm{K}$ and $\mathrm{Ca}$ are present in high concentrations (29.1 and $14.9 \mathrm{~g} \mathrm{~kg}^{-1}$, respectively), whereas $\mathrm{Mg}$ and $\mathrm{P}$ are less abundant (3.3. and $5.8 \mathrm{~g} \mathrm{~kg}^{-1}$, respectively). The total $\mathrm{Zn}$ and $\mathrm{Pb}$ concentrations were in the range proposed by the Spanish regulation for class $\mathrm{C}$ compost (Ministry of Agriculture 2005), while for the other metals class B requirements would be fulfilled. Therefore, the compost would be classified as " $\mathrm{C}$ compost" and should not be employed at rates higher than $5 \mathrm{Mg}$ dry matter ha ${ }^{-1}$ year $^{-1}$. Most concern is about $\mathrm{Zn}$ that has been commonly regarded as the metal with the highest availability in MSW composts (Paradelo et al. 2011, 2017).

Plots with organic amendment received 540 or $1080 \mathrm{~kg}$ total $\mathrm{N} \mathrm{ha}^{-1}$, from which only about $10 \%$ is considered to be available for a first culture (Hadas and Portnoy 1994). Based on available nutrient concentrations, the addition of
Table 1 Treatments assayed in the field trial and total amounts of nutrients added

\begin{tabular}{|c|c|c|c|c|c|c|}
\hline Key & Type & Fertilizer/Amendment & Rate $\left(\mathrm{Mg} \mathrm{ha}^{-1}\right)$ & $\mathrm{N}\left(\mathrm{kg} \mathrm{ha}^{-1}\right)$ & $\mathrm{P}_{2} \mathrm{O}_{5}\left(\mathrm{~kg} \mathrm{ha}^{-1}\right)$ & $\mathrm{K}_{2} \mathrm{O}\left(\mathrm{kg} \mathrm{ha}^{-1}\right)$ \\
\hline S & Control & None & - & - & - & - \\
\hline $\mathrm{SC} 1$ & Organic & MSWC & 30 & 540 & 135 & 653 \\
\hline $\mathrm{SC} 2$ & Organic & MSWC & 60 & 1080 & 270 & 1306 \\
\hline SIF & Inorganic & $\mathrm{NH}_{4} \mathrm{NO}_{3}+\mathrm{NPK} 12: 12: 24$ & $0.1+1.0$ & 141 & 120 & 240 \\
\hline
\end{tabular}

MSWC municipal solid waste compost 
Table 2 Characteristics of the compost

\begin{tabular}{|c|c|c|c|c|c|}
\hline & & & $\begin{array}{l}\text { Total } \\
\left(\mathrm{mg} \mathrm{kg}^{-1}\right)\end{array}$ & & $\begin{array}{l}\text { Available }^{\mathrm{a}} \\
\left(\mathrm{mg} \mathrm{kg}^{-1}\right)\end{array}$ \\
\hline $\mathrm{pH}$ in $\mathrm{H}_{2} \mathrm{O}$ & 7.5 & $\mathrm{Fe}$ & 11,039 & $\mathrm{Fe}$ & 981 \\
\hline $\mathrm{OM}\left(\mathrm{g} 100 \mathrm{~g}^{-1}\right)$ & 51.9 & $\mathrm{Zn}$ & 519 & $\mathrm{Zn}$ & 263 \\
\hline Total N $\left(\mathrm{g} 100 \mathrm{~g}^{-1}\right)$ & 2.4 & Mn & 295 & $\mathrm{Mn}$ & 164 \\
\hline $\mathrm{C} / \mathrm{N}$ & 13 & $\mathrm{~Pb}$ & 192 & $\mathrm{~Pb}$ & 51 \\
\hline $\mathrm{K}_{2} \mathrm{O}\left(\mathrm{g} \mathrm{kg}^{-1}\right)$ & 29.1 & $\mathrm{Cu}$ & 101 & $\mathrm{Cu}$ & 14 \\
\hline $\mathrm{CaO}\left(\mathrm{g} \mathrm{kg}^{-1}\right)$ & 14.9 & $\mathrm{Ni}$ & 25 & $\mathrm{Ni}$ & 5 \\
\hline $\operatorname{MgO}\left(\mathrm{g} \mathrm{kg}^{-1}\right)$ & 3.3 & $\mathrm{Cr}$ & 22 & $\mathrm{Cr}$ & 2 \\
\hline $\mathrm{P}_{2} \mathrm{O}_{5}\left(\mathrm{~g} \mathrm{~kg}^{-1}\right)$ & 5.8 & $\mathrm{Cd}$ & 1 & $\mathrm{Cd}$ & $<0.3$ \\
\hline
\end{tabular}

Concentrations are expressed on a dry weight basis. Moisture of fresh compost was $25 \%$

${ }^{a}$ Extracted in EDTA at $\mathrm{pH} 4.65$

30 and $60 \mathrm{t} \mathrm{ha}^{-1}$ compost also contributed 653 and $1306 \mathrm{~kg}$ $\mathrm{ha}^{-1}$ of $\mathrm{K}_{2} \mathrm{O}$, and 135 and $270 \mathrm{~kg} \mathrm{ha}^{-1}$ of $\mathrm{P}_{2} \mathrm{O}_{5}$, whereas inorganic fertilization provided $141 \mathrm{~kg} \mathrm{ha}^{-1} \mathrm{~N}, 120 \mathrm{~kg} \mathrm{ha}^{-1}$ $\mathrm{P}_{2} \mathrm{O}_{5}$ and $240 \mathrm{~kg} \mathrm{ha}^{-1} \mathrm{~K}_{2} \mathrm{O}$. One month after the application of the amendments and fertilizers the soil was tilled to $20 \mathrm{~cm}$ depth, and potatoes (Kennebec cultivar) were planted 1 week later, in June 2001.

\section{Sampling}

The soil was sampled 30 (1 month) and 150 days ( 5 months) after compost application; the last sampling was just before potato harvesting. Six subsamples were randomly collected from the top $15 \mathrm{~cm}$ of the central strips of subplots and mixed to constitute a composite sample representative of each subplot. Samples were transported in crush-proof plastic boxes to the laboratory, where they were sieved ( $<$ $5 \mathrm{~mm}$ ) and stored at $4{ }^{\circ} \mathrm{C}$ before the analysis. Biochemical analyzes, as well as $\mathrm{NH}_{4}{ }^{+}-\mathrm{N}$ and $\mathrm{NO}_{3}{ }^{-}-\mathrm{N}$ determinations, were carried out on field-moist soils, within 2 weeks of sampling. Chemical and physical analyzes were carried out on air-dried subsamples.

For potato harvesting, a $0.40 \mathrm{~m}$ buffer zone was established along the outer rim of each plot to minimize the edge effect. Potatoes were harvested outside this buffer area and yield was recorded.

\section{Soil analysis}

The physicochemical properties of the soils were determined as per Guitián and Carballas (1976). Soil pH was determined in water and $0.1 \mathrm{M} \mathrm{KCl}$ suspensions $(1: 2.5 \mathrm{w} / \mathrm{v})$ with a glass electrode. Organic $\mathrm{C}$ was analyzed by dichromate oxidation and titration with ferrous ammonium sulfate. Total $N$ was determined by the Kjeldahl method. Inorganic $N\left(\mathrm{NH}_{4}-\mathrm{N}+\mathrm{NO}_{3}-\mathrm{N}\right)$ was determined by extraction in $2 \mathrm{M}$
$\mathrm{KCl}$, followed by steam distillation (Keeney and Nelson 1982). Cation exchange capacity (CEC) was determined in $1 \mathrm{M} \mathrm{NH}_{4} \mathrm{OAc}$ (Gillman et al. 1983) and available $\mathrm{Ca}, \mathrm{Mg}$ and $\mathrm{K}$ determined by flame atomic absorption/emission spectroscopy (Varian SpectrAA 220FS, Varian Inc., Palo Alto, US). Available $\mathrm{P}$ was extracted in $\mathrm{NH}_{4} \mathrm{~F}-\mathrm{HCl}$ (Bray and Kurtz 1945) followed by colorimetric determination of the phosphomolybdic complex. Total $\mathrm{Mn}, \mathrm{Cr}, \mathrm{Cu}, \mathrm{Ni}, \mathrm{Pb}$ and $\mathrm{Zn}$ were analyzed by flame atomic absorption spectroscopy, after digestion in microwave oven with $\mathrm{HNO}_{3}, \mathrm{HCl}$ and $\mathrm{HF}$. Quality control of total element analyzes was performed by analyzing triplicate samples of a certified reference material (sewage sludge amended soil CRM-143) from the Community Bureau of Reference. The method of Lakanen and Erviö (1971) was used to extract $\mathrm{NH}_{4} \mathrm{OAc} /$ EDTA-soluble metals that were analyzed by flame atomic absorption spectroscopy.

Bulk density was determined in three undisturbed soil cores dried at $105^{\circ} \mathrm{C}$, and total porosity was calculated from particle density and bulk density. Particle density was determined in ground $(<50 \mu \mathrm{m})$ dry soil by the pycnometer method, using toluene as the filling liquid. The aggregate size distribution was determined after ten minutes of dry shaking in a sieving machine at medium intensity, from the weight fraction of aggregates retained on sieves with mesh size of 2 and $1 \mathrm{~mm}$, the top threshold of clods being $5 \mathrm{~mm}$ (Burke et al. 1986). Aggregate stability was determined by wet sieving following the method of Kemper and Rosenau (1986). The aggregate resistance to raindrop impact was determined by evenly spreading $50 \mathrm{~g}$ of soil sieved between 4 and $0.25 \mathrm{~mm}$ on a sieve of mesh size $0.25 \mathrm{~mm}$. The soil was subjected to $30 \mathrm{~min}$ of artificial rainfall simulated by ejecting water at an exit pressure of $0.25 \mathrm{~kg} \mathrm{~cm}^{-2}$ from an oscillating sprinkler at $2.5 \mathrm{~m}$ high over the soil. The simulated rain had a mean drop diameter $1.25 \mathrm{~mm}$, intensity $45 \mathrm{~mm} \mathrm{~h}^{-1}$ and a kinetic energy $14.38 \mathrm{~J} \mathrm{~m}^{2} \mathrm{~mm}^{-1}$. From the results of duplicate experiments, the proportion of soil loss was calculated $\left(\mathrm{g} \mathrm{m}^{-2} \mathrm{~min}^{-1}\right)$.

Microbial biomass $\mathrm{C}$ (MBC) was determined by the chloroform fumigation-extraction method (Vance et al. 1987). Dehydrogenase activity was determined by the reduction of 2,3,5-triphenyltetrazolium chloride (TTC) to triphenylformazan (TPF) following the method proposed by Tabatabai (1982).

\section{Plant analyzes}

The tubers were analyzed for their nutrient and total heavy metal concentrations, after microwave oven digestion of the potato tuber (dried at $70{ }^{\circ} \mathrm{C}$ ) in concentrated $\mathrm{HF}+\mathrm{HNO}_{3}+$ $\mathrm{H}_{2} \mathrm{O}_{2}$ and measuring of element concentration in the extracts by flame atomic absorption spectrometry (Varian SpectrAA 220FS, Varian Inc., Palo Alto, US). 


\section{Statistical analyzes}

Linear regression model analysis and one-way ANOVA were performed to assess the significance of the differences between the treatments and the control soil, using the R statistical package for MacOSX (version R 3.1.3; R Core Team 2015).

\section{Results and discussion}

\section{Soil physical properties}

The addition of compost significantly decreased soil bulk density and increased porosity at the highest dose, whereas at the low rate there was no effect (Table 3). Although aggregate size and aggregate stability did not change with compost application, soil loss under simulated rainfall did decrease in comparison with the control soil, even at the lowest compost dose. These modifications are overall positive to plant growth, because they are associated to higher moisture and water retention by the soils, as well as for other soil functions such as protection against erosion or a better habitat for microorganisms. Although increases in aggregate stability have also been commonly observed in compostamended soils (Hargreaves et al. 2008; Diacono and Montemurro 2010), this was not the case in our study. The high aggregate stability of these basic schist soils is due to the abundance of poorly crystalline Fe/Al (hydr)oxides (Arias et al. 2016) and can explain the lack of effect observed after the addition of compost.

\section{Soil chemical properties}

The chemical properties of the treated and control soils during the experiment are shown in Table 4. A significant increase in $\mathrm{pH}$ in $\mathrm{KCl}$ took place for the $\mathrm{SC} 2$ treatment, 5 months after the addition of compost. This $\mathrm{pH}$ increase is

Table 3 Physical properties of the soils after the experiment

\begin{tabular}{|c|c|c|c|c|c|c|c|c|}
\hline \multirow[t]{2}{*}{ Key } & \multirow[t]{2}{*}{ Fertilizer/Amendment } & \multirow{2}{*}{$\begin{array}{l}\text { Dry bulk density } \\
\mathrm{g} \mathrm{cm}^{-3}\end{array}$} & \multirow{2}{*}{$\begin{array}{l}\text { Total } \\
\text { porosity } \%\end{array}$} & \multicolumn{3}{|c|}{ Aggregate size distribution } & \multirow{2}{*}{$\begin{array}{l}\text { Aggregate } \\
\text { stability \% }\end{array}$} & \multirow{2}{*}{$\begin{array}{l}\text { Soil loss } \\
\mathrm{g} \mathrm{m}^{-2} \mathrm{~min}^{-1}\end{array}$} \\
\hline & & & & $\begin{array}{l}>2 \mathrm{~mm} \\
\%\end{array}$ & $\begin{array}{l}1-2 \mathrm{~mm} \\
\%\end{array}$ & $\begin{array}{l}<1 \mathrm{~mm} \\
\%\end{array}$ & & \\
\hline $\mathrm{S}$ & None & 1.31 & 49 & 35 & 29 & 36 & 29 & 63 \\
\hline SC1 & MSWC & 1.27 & 50 & 33 & 29 & 38 & 30 & $39^{*}$ \\
\hline $\mathrm{SC} 2$ & MSWC & $1.16^{*}$ & $54^{*}$ & 29 & 29 & 42 & 31 & $39^{*}$ \\
\hline SIF & $\mathrm{NH}_{4} \mathrm{NO}_{3}+\mathrm{NPK}$ & - & - & - & - & - & - & - \\
\hline
\end{tabular}

Statistically significant differences $(P<0.05)$ with respect to the control are indicated by an asterisk

- Not determined on the SIF plots

Table 4 Chemical properties of the soils during the experiment

\begin{tabular}{|c|c|c|c|c|c|c|c|c|c|c|c|c|c|}
\hline \multirow[t]{2}{*}{ Key } & \multirow[t]{2}{*}{ Fertilizer / Amendment } & \multicolumn{2}{|l|}{$\mathrm{pH}_{\mathrm{w}}$} & \multicolumn{2}{|c|}{$\mathrm{pH}_{\mathrm{KCl}}$} & \multicolumn{2}{|c|}{ TOC $\left(\mathrm{g} \mathrm{kg}^{-1}\right)$} & \multicolumn{2}{|c|}{$\mathrm{N}\left(\mathrm{g} \mathrm{kg}^{-1}\right)$} & \multicolumn{2}{|l|}{$\mathrm{C} / \mathrm{N}$} & \multicolumn{2}{|c|}{$\begin{array}{l}\operatorname{CEC}\left(\mathrm{cmol}_{\mathrm{c}}\right. \\
\left.\mathrm{kg}^{-1}\right)\end{array}$} \\
\hline & & Jul & Nov & Jul & Nov & Jul & Nov & Jul & Nov & Jul & Nov & Jul & Nov \\
\hline S & None & 5.7 & 5.9 & 5.2 & 5.4 & 15 & 11 & 1.3 & 1.3 & 12 & 9 & 9.9 & 9.7 \\
\hline SC1 & MSWC & 5.8 & 6.3 & 5.6 & 6.0 & 19 & 14 & $1.7^{*}$ & $1.6^{*}$ & 10 & 9 & 11.4 & 10.9 \\
\hline $\mathrm{SC} 2$ & MSWC & 6.1 & 6.8 & 6.1 & $6.5^{*}$ & $22^{*}$ & $20^{*}$ & $2.3^{*}$ & $2.2^{*}$ & 10 & 9 & $17.3^{*}$ & $15.8^{*}$ \\
\hline \multirow[t]{3}{*}{ SIF } & $\mathrm{NH}_{4} \mathrm{NO}_{3}+\mathrm{NPK}$ & 5.4 & 5.5 & 5.0 & 5.1 & 14 & 12 & 1.4 & 1.3 & 11 & 9 & 9.3 & 10.1 \\
\hline & & \multicolumn{2}{|c|}{$\begin{array}{l}\mathrm{NH}_{4}-\mathrm{N}(\mathrm{mg} \\
\left.\mathrm{kg}^{-1}\right)\end{array}$} & \multicolumn{2}{|c|}{$\begin{array}{l}\mathrm{NO}_{3}-\mathrm{N}(\mathrm{mg} \\
\left.\mathrm{kg}^{-1}\right)\end{array}$} & \multicolumn{2}{|c|}{$\mathrm{P}_{2} \mathrm{O}_{5}\left(\mathrm{mg} \mathrm{kg}^{-1}\right)$} & \multicolumn{2}{|c|}{$\mathrm{K}_{2} \mathrm{O}\left(\mathrm{mg} \mathrm{kg}^{-1}\right)$} & \multicolumn{2}{|c|}{$\mathrm{CaO}\left(\mathrm{mg} \mathrm{kg}^{-1}\right)$} & \multicolumn{2}{|c|}{$\begin{array}{l}\mathrm{MgO}(\mathrm{mg} \\
\left.\mathrm{kg}^{-1}\right)\end{array}$} \\
\hline & & Jul & Nov & Jul & Nov & Jul & Nov & Jul & Nov & Jul & Nov & Jul & Nov \\
\hline S & None & 1.3 & 1.1 & 33.6 & 21 & 369 & 395 & 1166 & 1160 & 1384 & 1363 & 78 & 69 \\
\hline SC1 & MSWC & 1.7 & 2.6 & $69.7^{*}$ & 46 & 489 & 512 & 1563 & $1661^{*}$ & 1958 & 1979 & $129^{*}$ & $119^{*}$ \\
\hline $\mathrm{SC} 2$ & MSWC & 2.2 & 3.9 & $105^{*}$ & 67 & $621^{*}$ & $603^{*}$ & $1973^{*}$ & $1916^{*}$ & $3184^{*}$ & $2913^{*}$ & $195^{*}$ & $154^{*}$ \\
\hline SIF & $\mathrm{NH}_{4} \mathrm{NO}_{3}+\mathrm{NPK}$ & $13.9^{9}$ & 2 & $94^{*}$ & 76 & 437 & 449 & 1375 & 1414 & 1298 & 1262 & 6 & 65 \\
\hline
\end{tabular}

Statistically significant differences $(P<0.05)$ with respect to the control are indicated by an asterisk

TOC total organic carbon, CEC cation exchange capacity, Jul sampling at July, Nov sampling at November 
commonly observed when acid soils are amended with urban waste composts (Hargreaves et al. 2008; Paradelo and Barral 2017), and is a consequence of the buffering capacity of organic matter and the presence of carbonates in municipal solid waste in this case (Vassilev et al. 1999; Paradelo et al. 2011). This liming effect is extremely important in these acid soils with variable charge and a high $\mathrm{P}$ fixation capacity. On the one hand, increase of $\mathrm{pH}$ contributes to the reduction of Al toxicity by decreasing the amount of exchangeable Al. On the other hand, higher $\mathrm{pH}$ means lower positive charge, and therefore, lower phosphate fixation, what is positive in terms of fertility. Additionally, liming can also contribute to increase $\mathrm{OC}$ sequestration in these soils by two mechanisms: increasing $\mathrm{C}$ protection by aggregates due to improved stability of clay assemblages and clay-organic matter bonds; and indirectly by increasing the return of $\mathrm{C}$ inputs to soil as a consequence of higher plant productivity in limed soils (Paradelo et al. 2015).

SOC contents were higher in the soils with the highest compost dose SC2 both in July and November, whereas total $\mathrm{N}$ concentrations were higher in $\mathrm{SC} 1$ and $\mathrm{SC} 2$ treatments (Table 4). Simultaneous increases in both parameters caused the $\mathrm{C} / \mathrm{N}$ ratio not to change significantly with treatments. Thus, compost addition increased organic matter concentrations even in these soils that were not previously poor, compared to most agricultural soils in Europe. These soils developed on basic rocks under Oceanic climate have a great potential for sequestering $\mathrm{OC}$ due to the presence of poorly crystalline $\mathrm{Fe}$ and $\mathrm{Al}$ compounds that highly stabilize organic matter (García-Rodeja et al. 1987), and indeed non-agricultural soils developed on these materials often present SOC concentrations over $50 \mathrm{~g} \mathrm{~kg}^{-1}$ (Calvo de Anta et al. 2015). Thus, the addition of urban waste composts is an interesting option for increasing SOC sequestration and $\mathrm{N}$ contents.

Nutrient concentrations and cation exchange capacity for the treated and control soils are also shown in Table 4. Cation exchange capacity was higher for $\mathrm{SC} 2$, what can be related to its higher $\mathrm{OC}$ concentration that contributes with negative charged surfaces responsible for cation exchange. Regarding available nutrients, only the inorganic fertilization produced significant increases in $\mathrm{NH}_{4}-\mathrm{N}, 1$ month after the application, in comparison with control soils. Nevertheless, this effect was lost at the harvest time, suggesting intense absorption of this nutrient by the crop. Nitrate $\left(\mathrm{NO}_{3}-\mathrm{N}\right)$, which represents the major part of inorganic $\mathrm{N}$ at the two sampling times, was higher for all the treatments in comparison with the control soil in the first sampling, but not in the second one, corroborating the intensive use of inorganic $\mathrm{N}$ by the crop and/or losses by leaching. The available $\mathrm{P}$ concentration was higher in $\mathrm{SC} 2$ in comparison with SIF and control soil, as was the available $\mathrm{K}_{2} \mathrm{O}$, and the same was true for available $\mathrm{Ca}$ and $\mathrm{Mg}$. Thus, compost addition increased the concentrations of essential plant nutrients ( $\mathrm{N}, \mathrm{P}$ and $\mathrm{K}$ ), in line with the capacity of compost for NPK supply that has been demonstrated in other studies (Hargreaves et al. 2008; Diacono and Montemurro 2010; Barral et al. 2011). This shows that, in addition to their effect as organic amendments, increasing or maintaining SOM contents, MSW composts used at concentrations similar or slightly higher than those usual for manure in the region are a valuable source of nutrients. However, in view of the high nutrient content of MSW composts, attention has to be paid to potential N and $\mathrm{P}$ losses through leaching. Under the climatic conditions of these oceanic regions, when these amendments are added to nutrient-rich soils, as is the case for the studied soil, excess $\mathrm{N}$ and $\mathrm{P}$ may be lixiviated from soils to water bodies. Here, the risk associated to $\mathrm{N}$ would be more important that in the case of $\mathrm{P}$, according to the large increment in available nitrate in the compost-amended soil (Table 4). Thus, both the dose of compost and the moment of application to agricultural soils are decisive factors to reduce or avoid $\mathrm{N}$ leaching.

\section{Soil biochemical properties}

The addition of MSW compost had favorable effects on soil biological activity, as it increased dehydrogenase activity at both doses, although biomass-C content was only higher for SC2 (Table 5). This is in agreement with results from several experiments that have demonstrated that soil biological properties such as microbial biomass $\mathrm{C}$ and enzymatic activities are significantly improved by compost addition (Paradelo et al. 2007, 2009b; Hargreaves et al. 2008; Diacono and Montemurro 2010). This effect of compost on biological activity is attributed to an increase in substrate availability to decomposer microorganisms, since they use organic carbon for energy trough respiration or for assimilation into their tissues. Better conditions for microorganisms and microbial activity are positive beyond the productive function of soil, as they will increase biodiversity and influence the biogeochemical cycles that are dependent on organic matter decomposition (Ros et al. 2006; Diacono and Montemurro 2010).

\section{Potato yield}

Despite all the improvements in soil conditions, potato yield did not increase with fertilization as it would be expected (Table 5). The positive effects of MSW compost (at least at the highest dose) on nutrient contents, porosity, stability against water erosion and biological activity were not reflected in the potato yield, but neither were found in the plots receiving inorganic fertilization. Several factors can explain this fact: (1) the increase in soil $\mathrm{pH}$ due to compost is not necessarily positive for potato, which is well adapted 
Table 5 Soil biological activity, potato yield and metal plant uptake: potato tuber composition

\begin{tabular}{|c|c|c|c|c|c|c|c|c|}
\hline \multirow[t]{2}{*}{ Key } & \multirow[t]{2}{*}{ Fertilizer/Amendment } & \multicolumn{2}{|l|}{ Soil } & \multirow{2}{*}{$\begin{array}{l}\text { Potato } \\
\text { yield (Q } \\
\left.\mathrm{ha}^{-1}\right)\end{array}$} & \multicolumn{4}{|l|}{ Potato } \\
\hline & & $\begin{array}{l}\text { Dehydroge- } \\
\text { nase activity } \\
\left(\mathrm{mg} \mathrm{TPF}^{-1} \mathrm{~kg}^{-1}\right)^{-1}\end{array}$ & $\begin{array}{l}\text { Microbial } \\
\text { biomass C (mg } \\
\left.\mathrm{kg}^{-1}\right)\end{array}$ & & $\mathrm{Fe}\left(\mathrm{mg} \mathrm{kg}^{-1}\right)$ & $\operatorname{Mn}\left(\mathrm{mg} \mathrm{kg}^{-1}\right)$ & $\mathrm{Cu}\left(\mathrm{mg} \mathrm{kg}^{-1}\right)$ & $\mathrm{Zn}\left(\mathrm{mg} \mathrm{kg}^{-1}\right)$ \\
\hline $\mathrm{S}$ & None & 77 & 65 & 58.9 & 49 & 4.8 & 7.8 & 14.1 \\
\hline SC1 & MSWC & 104 & $120^{*}$ & 53.9 & 55 & 5.1 & 9.7 & 15.2 \\
\hline $\mathrm{SC} 2$ & MSWC & $132^{*}$ & $254^{*}$ & 49.8 & 73 & 5.3 & 9.4 & 17.9 \\
\hline SIF & $\mathrm{NH}_{4} \mathrm{NO}_{3}+\mathrm{NPK}$ & 67 & 70 & 58.8 & 89 & 5.4 & 7.9 & 12.6 \\
\hline
\end{tabular}

$\mathrm{Ni}, \mathrm{Pb}, \mathrm{Cr}$, and $\mathrm{Cd}$ concentrations were under the detection limits. Statistically significant differences $(P<0.05)$ with respect to the control are indicated by an asterisk

to acid soils; (2) the soil used had already a high fertility status, which met the requirements for potato growth without additional fertilization or amendment as shown by nutrient analyses of the control unfertilized plots (Table 4), and this could mask any positive short-term effect of compost; and (3) it has been noted that the best agronomic performance of MSW compost is often obtained as a slow-release nitrogen fertilizer and that it is less effective in the first year of application (Diacono and Montemurro 2010). The combination of these three facts explains why no increase in potato yield has been observed in our short-term study.

\section{Heavy metals in soil and plant}

In what concerns potentially toxic trace elements, which is the most studied risk in soils amended with urban wastes, the elements that were present at higher concentrations in the MSW compost employed here were $\mathrm{Zn}$ and $\mathrm{Pb}$ (Table 2), as commonly observed in compost studies (Smith 2009; Lopes et al. 2011; Paradelo et al. 2011; Rajaie and Tavakoly 2016). The total concentrations of metals in the compostamended soils were not modified, as shown in Table 6 (there were no differences in soil metal composition from June to November, so only November data are shown). In turn, a significant increase in available $\mathrm{Cu}, \mathrm{Ni}, \mathrm{Pb}$, and $\mathrm{Zn}$ was observed for the highest compost dose, the latter two elements being more problematic due to their higher potential toxicity. This availability increase is in agreement with what has been observed in similar soils (Paradelo and Barral 2017; Paradelo et al. 2018). Previous laboratory studies with several Galician soils and composts have shown that the risk related to heavy metals in compost-amended soils is mostly due to $\mathrm{Cu}, \mathrm{Pb}$, and $\mathrm{Zn}$ and that among them, the highest environmental risk is that of $\mathrm{Zn}$, that is the element with the highest concentrations in readily available soluble forms (Paradelo and Barral 2017; Paradelo et al. 2018). From a more general point of view, the quality of MSW compost could be substantially improved in what concerns metal contents with a more efficient source-separation of wastes, given that these elements reach the organic fraction of urban wastes during contact with ceramics, plastics, printed paper, and metallic particles (Haug et al. 1993; Paradelo et al. 2009a).

These observations obtained from soil analyses need to be complemented by studies on plant uptake. In this sense, the analysis of potato tubers in this study has shown that there was no additional metal transference to plant due to compost amendment (Table 5), despite the increase in metal availability. This fact is likely due to the liming effect of compost, since metal uptake is generally lower as soil $\mathrm{pH}$ increases (Smith 2009). These results show that, at least in the short-term, the risk associated to the use of MSW compost as organic amendment in these fertile agricultural soils is low. However, the long-term effects of repeated
Table 6 Trace element contents in the soils in November (total and available)

\begin{tabular}{|c|c|c|c|c|c|c|c|c|c|c|c|c|}
\hline \multirow[t]{2}{*}{ Key } & \multirow[b]{2}{*}{ Fertilizer/amendment } & \multicolumn{6}{|c|}{ Total $\left(\mathrm{mg} \mathrm{kg}^{-1}\right)$} & \multicolumn{5}{|c|}{ Available $\left(\mathrm{mg} \mathrm{kg}^{-1}\right)$} \\
\hline & & $\mathrm{Cu}$ & $\mathrm{Pb}$ & $\mathrm{Zn}$ & Co & $\mathrm{Ni}$ & $\mathrm{Cr}$ & $\mathrm{Cu}$ & $\mathrm{Pb}$ & $\mathrm{Zn}$ & Co & $\mathrm{Ni}$ \\
\hline$S$ & None & 40 & 156 & 102 & 66 & 71 & 77 & 2.2 & 3.9 & 1.3 & 0.7 & 0.3 \\
\hline $\mathrm{SC} 1$ & MSWC & 39 & 157 & 105 & 66 & 73 & 74 & 2.7 & 5.9 & 3.6 & 0.7 & 0.4 \\
\hline $\mathrm{SC} 2$ & MSWC & 41 & 154 & 126 & 59 & 68 & 74 & $3.4^{*}$ & $11.3^{*}$ & $9.2^{*}$ & 0.8 & 0.5 \\
\hline SIF & $\mathrm{NH}_{4} \mathrm{NO}_{3}+\mathrm{NPK}$ & 39 & 157 & 98 & 66 & 74 & 73 & 2.2 & 3.7 & 1.2 & 0.8 & 0.3 \\
\hline
\end{tabular}

Total $\mathrm{Cd}$ and available $\mathrm{Cr}$ and $\mathrm{Cd}$ concentrations were under the detection limits in all cases. Statistically significant differences $(P<0.05)$ with respect to the control are indicated by an asterisk 
applications of compost on the transference of toxic elements to plants could be different and should be studied in longer field experiments.

\section{Conclusions}

The addition of a MSW compost to a fertile, organic matterrich soil at doses of 30 or $60 \mathrm{Mg} \mathrm{ha}^{-1}$ produced a series of modifications in the soil physical, chemical and biological properties in comparison with soils receiving inorganic fertilization and with untreated control soils, although it did not influence potato yield. Positive effects for soil functions include increases of organic matter and porosity, correction of acid soil $\mathrm{pH}$ and increase in microbial activity. Higher available concentrations of $\mathrm{Cu}, \mathrm{Pb}$, and $\mathrm{Zn}$ were observed in compost-amended soils, but neither total metal concentrations in soil nor metal uptake by potato were increased by compost addition. Overall, the positive effects observed prove the benefits of recycling urban wastes in agricultural soils as a sustainable way of waste management. To achieve a safe application of MSW compost and to obtain the maximum beneficial effects without the detrimental effects of the accumulation of heavy metals in the environment after repeated amendment, it is recommended that compost quality be optimized by better source-separation of waste.

Open Access This article is distributed under the terms of the Creative Commons Attribution 4.0 International License (http://creativeco mmons.org/licenses/by/4.0/), which permits unrestricted use, distribution, and reproduction in any medium, provided you give appropriate credit to the original author(s) and the source, provide a link to the Creative Commons license, and indicate if changes were made.

\section{References}

Arias M, Conde M, Paradelo R (2016) Poorly-crystalline components in aggregates from soils under different land use and parent material. CATENA 144:141-150. https://doi.org/10.1016/j.caten a.2016.05.012

Barral MT, Paradelo R (2011) Trace elements in compost regulation: the case of Spain. Waste Manage 31:407-410. https://doi. org/10.1016/j.wasman.2010.10.019

Barral MT, Paradelo R, Moldes AB, Domínguez M, Díaz-Fierros F (2009) Utilization of MSW compost for organic matter conservation in agricultural soils of NW Spain. Resour Conserv Recycl 53:529-534. https://doi.org/10.1016/j.resconrec.2009.04.001

Barral MT, Paradelo R, Domínguez M, Díaz-Fierros F (2011) Nutrient release dynamics in soils amended with municipal solid waste compost in laboratory incubations. Compost Sci Util 19:235-243. https://doi.org/10.1080/1065657X.2011.10737007

Bray R, Kurtz L (1945) Determination of total organic and available forms of phosphorus in soil. Soil Sci 59:39-45

Burke W, Gabriels D, Bouma J (1986) Soil structure assessment. A.A. Balkema, Boston
Calvo de Anta R, Luís Calvo E, Casás Sabarís F, Galiñanes Costa JM, Matilla Mosquera N, Vázquez FM, Camps Arbestain M, Vázquez García N (2015) Soil organic carbon in northern Spain (Galicia, Asturias, Cantabria and País Vasco). Span J Soil Sci 5:41-53. https://doi.org/10.3232/SJSS.2015.V5.N1.04

Chaney RL, Ryan JA, Kukier U, Brown SL, Siebielec G, Malik M, Angle JS (2001) Heavy metal aspects of compost use. In: Stoffella PJ, Kahn BA (eds) Compost utilization in horticultural cropping systems. CRC Press, Boca Raton, pp 323-359

Diacono M, Montemurro F (2010) Long-term effects of organic amendments on soil fertility A review. Agron Sustain Develop 30:410-422. https://doi.org/10.1051/agro/2009040

Farrell M, Jones DL (2009) Critical evaluation of municipal solid waste composting and potential compost markets. Bioresour Technol 100:4301-4310. https://doi.org/10.1016/j.biortech.2009.04.029

García-Rodeja E, Silva B, Macías F (1987) Andosols developed from non-volcanic materials in Galicia, NW Spain. J Soil Sci 38:573591. https://doi.org/10.1111/j.1365-2389.1987.tb02156.x

Gillman GP, Bruce RC, Davey BG, Kimble JM, Searle PL, Skjemstad JO (1983) A comparison of methods used for determination of cation exchange capacity. Commun Soil Sci Plant Anal 14:10051014. https://doi.org/10.1080/00103628309367428

Guitián F, Carballas T (1976) Técnicas de análisis de suelos. Pico Sacro, Santiago de Compostela (Spain)

Hadas A, Portnoy R (1994) Nitrogen and carbon mineralization rates of composted manures incubated in soil. J Environ Qual 23:11841189 https://doi.org/10.2134/jeq1994.00472425002300060008x

Hargreaves JC, Adl MS, Warman PR (2008) A review of the use of composted municipal solid waste in agriculture. Agric Ecosyst Environ 123:1-14. https://doi.org/10.1016/j.agee.2007.07.004

Haug RT (1993) The practical book of compost engineering. Lewis Publishers, Boca Raton

IUSS Working Group WRB (2014) World Reference Base for Soil Resources 2014. International soil classification system for naming soils and creating legends for soil maps. World Soil Resources Reports No. 106. FAO, Rome.

Keeney, D.R. and D.W. Nelson. 1982. Nitrogen-Inorganic forms. In: Page AL (ed) Methods of Soil Analysis. Part 2. Chemical and microbiological properties. American Society of Agronomy, Madison, pp 643-698

Kemper WD, Rosenau RC (1986) Aggregate stability and size distribution. In: Klute A (ed) Methods of Soil Analysis, part I. Physical and Mineralogical methods. American Society of Agronomy, Madison, pp 427-442

Lakanen E, Erviö RA (1971) A comparison of eight extractants for the determination of plant-available micronutrients in soils. Acta Agralia Fennica 123:223-232

Lopes C, Herva M, Franco-Uría A, Roca E (2011) Inventory of heavy metal content in organic waste applied as fertilizer in agriculture: evaluating the risk of transfer into the food chain. Environ Sci Pollut Res 18:918-939. https://doi.org/10.1007/s11356-011-0444-1

Ministry of Agriculture (2005) Real Decreto 824/2005, de 18 de junio, sobre fertilizantes. Span Off Bull 171:25592-25669

Paradelo R (2013) Use of compost for the restoration of mine wastes and mine soils (in Spanish). Bol Geol Miner 124:405-419

Paradelo R, Barral MT (2017) Availability and fractionation of $\mathrm{Cu}, \mathrm{Pb}$ and $\mathrm{Zn}$ in an acid soil from Galicia (NW Spain) amended with municipal solid waste compost. Span J Soil Sci 7:17-25. https:// doi.org/10.3232/SJSS.2017.V7.N1.03

Paradelo R, Cendón Y, Moldes AB, Barral MT (2007) A pot experiment with mixtures of slate processing fines and compost. Geoderma 141:363-369. https://doi.org/10.1016/j.geode rma.2007.07.002

Paradelo R, Moldes AB, Barral MT (2009a) Magnetic susceptibility as an indicator of heavy metal contamination in compost. Waste 
Manage Res 27:46-51. https://doi.org/10.1177/0734242X07 082962

Paradelo R, Moldes AB, Barral MT (2009b) Properties of slate mining wastes incubated with grape marc compost under laboratory conditions. Waste Manage 29:579-584. https://doi.org/10.1016/j. wasman.2008.06.019

Paradelo R, Villada A, Devesa-Rey R, Moldes AB, Domínguez M, Patiño J, Barral MT (2011) Distribution and availability of trace elements in municipal solid waste composts. J Environ Monitor 13:201-211. https://doi.org/10.1039/C0EM00408A

Paradelo R, Virto I, Chenu C (2015) Net effect of liming on soil organic carbon stocks: a review. Agric Ecosyst Environ 202:98-107. https ://doi.org/10.1016/j.agee.2015.01.005

Paradelo R, Cambier P, Jara A, Jaulin A, Doublet J, Houot S (2017) Mobility of $\mathrm{Cu}$ and $\mathrm{Zn}$ in soil amended with composts at different degrees of maturity. Waste Biomass Valor 8:633-643. https://doi. org/10.1007/s12649-016-9641-y

Paradelo R, Villada A, Barral MT (2018) Chemical fractionation of trace elements in a metal-rich amphibolite soil amended with municipal solid waste composts. Waste Biomass Valor 9:19351943. https://doi.org/10.1007/s12649-017-9940-y

Park JH, Lamb D, Paneerselvam P, Choppala G, Bolan N, Chung J-W (2011) Role of organic amendments on enhanced bioremediation of heavy metal(loid) contaminated soils. J Hazard Mater 185:549_ 574. https://doi.org/10.1016/j.jhazmat.2010.09.082

R Core Team (2015) R: a language and environment for statistical computing. R Foundation for Statistical Computing, Vienna, Austria http://www.R-project.org/. Accessed 5 Feb 2019

Rady MM, Semida WM, Hemida KA et al (2016) The effect of compost on growth and yield of Phaseolus vulgaris plants grown under saline soil. Int J Recycl Org Waste Agricult 5:311-321. https://doi.org/10.1007/s40093-016-0141-7
Rajaie M, Tavakoly AR (2016) Effects of municipal waste compost and nitrogen fertilizer on growth and mineral composition of tomato. Int J Recycl Org Waste Agric 5:339-347. https://doi.org/10.1007/ s40093-016-0144-4

Ros M, Klammer S, Knapp B, Aichberger K, Insam H (2006) Longterm effects of compost amendment of soil on functional and structural diversity and microbial activity. Soil Use Manag 22:209-218. https://doi.org/10.1111/j.1475-2743.2006.00027.x

Smith S (2009) A critical review of the bioavailability and impacts of heavy metals in municipal solid waste composts compared to sewage sludge. Environ Int 35:142-156. https://doi.org/10.1016/j. envint.2008.06.009

Tabatabai MA (1982) Soil enzymes. In: Page AL, Miller RH, Keeney DR (eds) Methods of Soil Analysis. II: Chemical and Microbiological properties. American Society of Agronomy, Madison, pp 903-947

Vance ED, Brookes PC, Jenkinson D (1987) An extraction method for measuring microbial biomass carbon. Soil Biol Biochem 19:703707. https://doi.org/10.1016/0038-0717(87)90052-6

Vassilev SV, Braekman-Danheux C, Laurent P (1999) Characterization of refuse-derived char from municipal solid waste: 1 . Phase-mineral and chemical composition. Fuel Proces Technol 59:95-134. https://doi.org/10.1016/S0378-3820(99)00017-X

Publisher's Note Springer Nature remains neutral with regard to jurisdictional claims in published maps and institutional affiliations. 